\title{
Model Inhomogeneous Spatial Cox Processes Untuk Pemetaan Risiko Gempabumi di Pulau Jawa
}

\author{
Finola Trisnisa, Rahma Metrikasari, Rifqi Rabbanie, Khalimatus Sakdiyah, dan Achmad Choiruddin \\ Departemen Statistika, Fakultas Matematika, Komputasi, dan Sains Data \\ Institut Teknologi Sepuluh Nopember (ITS) \\ Jl. Arief Rahman Hakim, Surabaya 60111 Indonesia \\ e-mail: choiruddin@its.ac.id
}

\begin{abstract}
Abstrak-Pulau Jawa menjadi salah satu wilayah dengan risiko gempabumi yang tinggi karena terdapat zona subduksi di sepanjang selatan wilayah pulau Jawa. Metode Statistika untuk pemodelan kejadian gempabumi berdasarkan spatial point processes menjadi metode popular untuk memodelkan persebaran gempabumi, diantaranya adalah model Gibbs dan Hawkes point processes (conditional intensity-based modeling) dan Cox point processes (intensity-based modeling). Pemodelan gempabumi menggunakan Hawkes dan Gibbs point processes dengan memperhatikan faktor geologi seperti sesar aktif, gunung berapi, dan subduksi telah dikembangkan. Namun demikian, Pemodelan berdasarkan conditional intensity dinilai kurang sesuai untuk pemodelan kejadian gempabumi di Jawa. Sementara itu, belum ada penelitian yang menggunakan Cox processes untuk memodelkan distribusi dari gempabumi dengan mempertimbangkan faktor geologi. Pada model Cox processes, estimasi parameter sangat sulit dilakukan karena fungsi likelihoodnya bergantung pada fungsi intensitas yang merupakan proses stokastik. Pada penelitian ini, kami mengembangkan salah satu model Cox point processes yakni Neyman-Scott Cox Process untuk analisis data lokasi gempabumi di pulau Jawa dengan memperhatikan faktor geologi seperti gunung berapi dan subduksi. Estimasi parameter dilakukan dengan membangun composite likelihood sehingga estimasi parameter lebih mudah dilakukan. Hasil analisis menunjukkan bahwa kejadian gempabumi di pulau Jawa membentuk pola kluster. Selain itu, jarak menuju gunung berapi dan subduksi terdekat dianggap signifikan berpengaruh terhadap distribusi gempabumi di pulau Jawa.

Kata Kunci-Spatial Point Processes, Neyman-Scott Cox Process, Gempabumi, Pulau Jawa.
\end{abstract}

\section{PENDAHULUAN}

$\mathrm{B}$ encana menurut Undang-Undang No. 27 Tahun 2007 diartikan sebagai peristiwa yang mengancam dan mengganggu kehidupan dan penghidupan masyarakat yang disebabkan, baik oleh faktor alam dan/atau faktor nonalam maupun faktor manusia sehingga mengakibatkan timbulnya korban jiwa manusia, kerusakan lingkungan, kerugian harta benda, dan dampak psikologis. Bencana dapat mengancam seluruh wilayah yang ada di Indonesia baik di daratan maupun di lautan. Indonesia merupakan kawasan yang sering mengalami kejadian bencana alam berupa gempabumi karena terletak di pertemuan tiga lempeng tektonik besar, yaitu Lempeng Pacifik, Indo_Australia, dan Eurasia. Hal ini membuat Indonesia menjadi Negara dengan tingkat kerawanan gempa yang cukup tinggi [1]. Wilayah yang rawan bencana gempa adalah wilayah Jawa, Bali, dan Nusa Tenggara Barat (NTB).
Tektonik Wilayah Jawa dan sekitarnya diduga dipengaruhi oleh jarak lokasi gempa dengan gunung berapi. Selain itu dipengarui oleh subduksi Lempeng Indo-Australia terhadap Lempeng Eurasia yang membentuk sistim Busur Sunda di daerah offshore yang terdiri dari palung Jawa, pungguan Jawa, dan cekungan busur [2]. Seismisitas dari zona subduksi dipengaruhi oleh umur, komposisi, dan kecepatan penunjaman dari lempeng subduksi. Faktor-faktor ini akan mempengaruhi frekuensi dan magnitudo kejadian gempa sepanjang Busur Sunda. Dampak dari kondisi tektonik tersebut mengakibatkan daerah-daerah di sepanjang busur Sunda sepert Pulau Jawa, Bali, dan NTB menjadi daeraha dengan tingkat kerawanan gempa yang relatif tinggi. Selama 25 tahun terakhir, wilayah Pulau Jawa dan sekitarnya setidaknya pernah diguncang 39 kejadian gempa dengan magnitude di atas 6 Skala Ricter (SR). Tingginya tingkat kerawanan gempa di wilayah tersebut perlu mendapatkan perhatian khusus mengingat hingga sekarang gempa merupakan bencana yang belum dapat di prediksi baik waktu, kekuatan maupun tempat kejadiannya. Dengan demikian bencana gempa memiliki potensi menimbulkan korban, kerusakan, dan kerugian dalam jumlah yang besar.

Upaya mitigasi perlu dilakukan secara dini dan optimal untuk meminimilasi dampak bencana gempa tersebut. Salah satu upaya mitigasi yang perlu dilakukan adalah dengan membuat peta titik-titik lokasi yang rawan gempa di Pulau Jawa dengan metode Newman-Scott Cox Process (NSCP). Penelitian tentang gempa dengan menggunakan data Spatial Point Pattern (SPP) dengan metode Epidemic-Type Aftershock Sequence (ETAS) dan estimasi parameternya dengan menggunakan Maximum Likelihood Estimation (MLE) sebelumnya pernah dilakukan oleh Bray dan Schoenberg tahun 2013. Penilitian lainnya dengan topik yang sama dilakukan Fung Yip dkk. pada tahun 2017, dimana penelitian ini metode yang digunakan juga ETAS dengan tambahan kovariat. Oleh karena itu, dari penelitian ini didapatkan hasil pemetaan yang dapat dimanfaatkan untuk melakukan upaya-upaya peringatan dini dalam meminimalisasi, baik korban jiwa maupun korban materil di Pulau Jawa.

Berdasarkan paparan sebelumnya, pada paper ini akan dilakukan penelitian tentang karakteristik gempabumi yang terjadi di Pulau Jawa dan pemetaan hasil prediksi gempabumi di Pulau Jawa. Batasan masalah yang digunakan dalam 
penelitian ini yaitu observation window yang dibatasi latitude lebih dari -5.905832 dan kurang dari -9.147764 serta longitude kurang dari 104.982986 dan lebih dari 114.600356. Kemudian data yang digunakan adalah gempa yang terjadi diantara tahun 2009-2018. Covariate yang digunakan adalah jarak titik gempa dengan gunung berapi dan jarak titik gempa dengan subduksi. Hasil dari penelitian ini dapat digunakan untuk mendapatkan titik-titik lokasi yang rawan terjadi gempa sehingga bisa menjadi preferensi dalam peringatan dini atau penanggulangan gempa, khususnya di Pulau Jawa.

\section{METODOLOGI PENELITIAN}

\section{A. Sumber Data}

Sumber data yang digunakan pada penelitian ini adalah data sekunder yang diambil dari laman web BMKG www.bmkg.go.id dimana data yang diambil yaitu tentang gempabumi di Indonesia yang meliputi titik terjadinya gempa (longitude dan latitude), gunung berapi, dan subduksi dengan periode data diambil dari tahun 2009 hingga 2018.

\section{B. Variabel Penelitian}

Peta tematik merupakan gambaran dari sebagian permukaan bumi yang dilengkapi dengan informasi yang mengandung tema tertentu yang berupa data kualitatif maupun kuantitatif. Peta tematik mempunyai hubungan atau hampir sama dengan SIG atau Sistem Informasi Geografis. Itu disebabkan karena pada umumnya hasil dari proyek SIG berupa peta

Variabel penelitian yang digunakan dalam penelitian ini yaitu titik terjadinya gempa (longitude dan latitude), gunung berapi, dan subduksi. Adapun struktur gempabumi penelitian dapat dilihat pada Tabel 2.1 berikut.

\begin{tabular}{|c|c|c|}
\hline Gempa Ke- & Latitude ( $\left.{ }^{\circ}\right)$ & Longitude $\left(^{\circ}\right)$ \\
\hline 1 & $\mathrm{X}_{1,1}$ & $\mathrm{X}_{2,1}$ \\
\hline 2 & $\mathrm{X}_{1,2}$ & $\mathrm{X}_{2,2}$ \\
\hline$\vdots$ & $\vdots$ & $\vdots$ \\
\hline 43789 & $X_{1,43789}$ & $X_{2,43789}$ \\
\hline 43790 & $X_{1,43790}$ & $X_{2,43790}$ \\
\hline
\end{tabular}

Struktur data untuk subduksi di Indonesia dapat dilihat pada Tabel 2.2 berikut.

Tabel 2.2 Struktur Data Subduksi

\begin{tabular}{|c|c|c|}
\hline Subduksi Ke- & Latitude $\left({ }^{\circ}\right)$ & Longitude $\left({ }^{\circ}\right)$ \\
\hline 1 & $\mathrm{Y}_{1,1}$ & $\mathrm{Y}_{2,1}$ \\
\hline 2 & $\mathrm{Y}_{1,2}$ & $\mathrm{Y}_{2,2}$ \\
\hline$\vdots$ & $\vdots$ & $\vdots$ \\
\hline 77 & $\mathrm{Y}_{1,77}$ & $\mathrm{Y}_{2,77}$ \\
\hline 78 & $\mathrm{Y}_{1,78}$ & $\mathrm{Y}_{2,78}$ \\
\hline
\end{tabular}

Sedangkan struktur data untuk gunung berapi di Indonesia dapat dilihat pada Tabel 2.3 berikut
Tabel 2.3 Struktur Data Gunung Berapi

\begin{tabular}{|c|c|c|}
\hline Gunung Berapi Ke- & Latitude $\left(^{\circ}\right)$ & Longitude $\left(^{\circ}\right)$ \\
\hline 1 & $\mathrm{Z}_{1,1}$ & $\mathrm{Z}_{2,1}$ \\
\hline 2 & $\mathrm{Z}_{1,2}$ & $\mathrm{Z}_{2,2}$ \\
\hline$\vdots$ & $\vdots$ & $\vdots$ \\
\hline 126 & $\mathrm{Z}_{1,126}$ & $\mathrm{Z}_{2,126}$ \\
\hline 127 & $\mathrm{Z}_{1,127}$ & $Z_{2,127}$ \\
\hline
\end{tabular}

\section{Langkah Penelitian}

Adapun langkah-langkah penelitian yang dilakukan pada penelitian ini yaitu sebagai berikut.

a. Menentukan observation window wilayah Pulau Jawa

b. Memotong data sesuai dengan observation window yang telah ditentukan

c. Melakukan visualisai pada data gempa, subduksi, dan gunung berapi dengan menggunakan Software $R$

d. Melakukan uji stasioneritas dengan chisquared test

e. Plot Ripley K-function dengan menggunakan fungsi Kinhom pada Software $R$ untuk melngetahui point pattern dari data

f. Estimasi parameter untuk memprediksi gempabumi dengan memperhitungkan jarak terjadinya gempabumi dengan lokasi gunung berapi dan subduksi di Pulau Jawa

g. Mendapatkan model untuk memprediksi terjadinya gempabumi di Pulau Jawa

h. Visualisasi prediksi terjadinya gempabumi di Pulau Jawa

i. Menarik kesimpulan dan saran

\section{Gempa Bumi}

Gempabumi adalah peristiwa bergetarnya bumi karena pergerakan atau pergeseran lapisan batuan pada kulit bumi secara tiba-tiba. Berdasarkan penyebabnya, gempabumi dikelompokkan menjadi 5 macam yaitu tektonik, vulkanik, runtuhan, jatuhan meteor, dan gempabumi buatan manusia. Gempabumi tektonik adalah gempabumi yang disebabkan oleh pelepasan energi elastis yang tersimpan dalam lempeng tektonik. Gempabumi vulkanik adalah gempabumi yang disebabkan oleh kegiatan gunung berapi serta dapat dipicu oleh aktivitas gempabumi tektonik. Gempabumi runtuhan adalah gempabumi yang terjadi ketika suatu gua atau lokasi pertambangan runtuh. Gempabumi yang disebabkan oleh manusia adalah peledakan dinamit, nuklir, ledakan bom [3].

\section{E. Spatial Point Process}

Spatial point process adalah pola acak titik-titik dalam ruang d-dimensi yang berguna sebagai model statistik pola titik yang diamati,di mana titik-titik tersebut mewakili lokasi beberapa objek penelitian. Salah satu point process yang mengasumsikan bahwa tidak terdapat hubungan antar lokasi satu dengan lokasi yang lain adalah poisson point process [4]. 
F. Neymann Scott Cox Process Second Order Composite Likelihood

Model clustered point process [4-5] dapat diperoleh dengan menggunakan composite loglikelihood dengan mendasarkan pada intensitas moment yang kedua yaitu $\lambda_{2}(u, v ; \boldsymbol{\theta})$.

$$
\begin{aligned}
\log C L(\boldsymbol{\theta})= & \sum_{i} \sum_{j \neq i} w\left(x_{i,} x_{j}\right)\left[\log \lambda_{2}\left(x_{i,} x_{j} ; \boldsymbol{\theta}\right)-\right. \\
& \left.\log \iint_{w} w(u, v) \lambda_{2}(u, v ; \boldsymbol{\theta}) d u d v\right)
\end{aligned}
$$

Dimana $w$ adalah fungsi bobot, untuk memudahkan perhitungan maka $w(u, v)=\mathbf{1}\{\|u-v\| \leq R\}$ dimana $\quad R>0$ adalah batas atas dari korelasi jarak model. Fungsi composite score dapat ditulis sebagai berikut.

$$
\begin{aligned}
\frac{\partial}{\partial \boldsymbol{\theta}} \log C L(\boldsymbol{\theta})= & \sum_{i} \sum_{j \neq 1} w\left(x_{i}, x_{j}\right) \frac{k_{2}\left(x_{i}, x_{j} ; \boldsymbol{\theta}\right)}{\lambda_{2}\left(x_{i}, x_{j} ; \boldsymbol{\theta}\right)}- \\
& \sum_{i} \sum_{j} w\left(x_{i}, x_{j}\right) \frac{\left(k_{2}, w\right)}{\left(\lambda_{2}, w\right)}
\end{aligned}
$$

\section{ANALSIS DAN PEMBAHASAN}

A. Sumber Data Visualisasi Kejadian Gempabumi di Pulau Jawa Tahun 2009-2018

Gempabumi di wilayah Pulau Jawa dapat digambarkan dengan melihat point pattern dengan menggunakan Software $R$. Berikut merupakan hasil visualisasi gempabumi di Pulau Jawa.

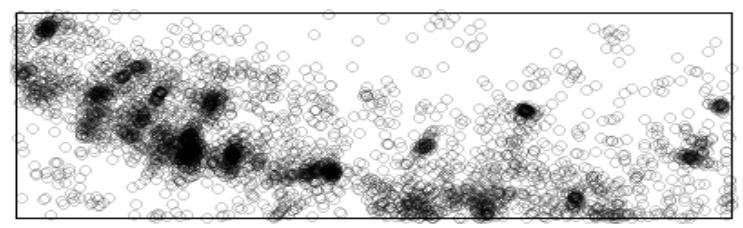

(a)

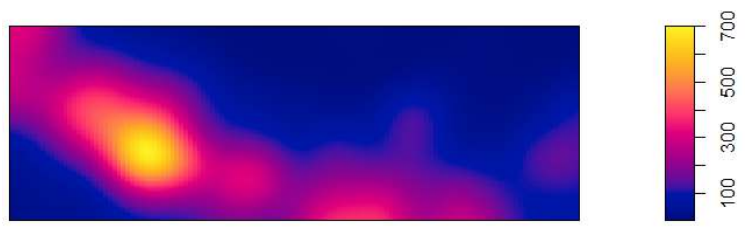

(b)

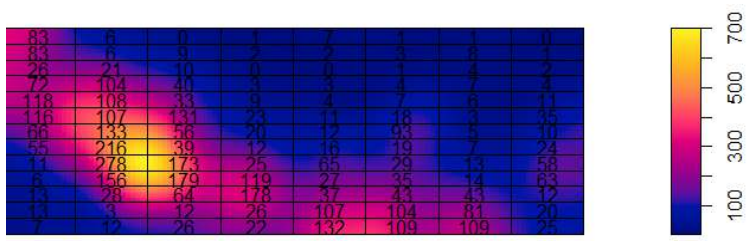

(c)

Gambar 3.1. Intensitas Gempabumi di Pulau Jawa

Gambar 3.1 (a) merupakan plot persebaran gempabumi di Pulau Jawa pada tahun 2009-2018 dalam bentuk point pattern. Berdasarkan Gambar 3.1 (b) dapat diketahui intensitas gempabumi di Pulau Jawa, jika warna area semakin cerah menandakan bahwa area tersebut memiliki intensitas gempabumi yang semakin tinggi. Hal ini dijelaskan pada Gambar 1 (c) yang menunjukkan jumlah gempabumi pada setiap unit square area dimana jumlah paling banyak terjadi gempabumi pada unit square area yang berwarna cerah yaitu sebesar 278 dan 216 kejadian. Dari hasil ketiga plot tersebut, dapat dilihat bahwa gempabumi banyak terjadi di bagian barat Pulau Jawa.

\section{B. Variabel Penelitian Visualisasi Jarak Gunung Berapi} dengan Kejadian Gempabumi di Pulau Jawa

Berikut merupakan hasil visualisasi lokasi gunung berapi dengan kejadian gempabumi di Pulau Jawa.

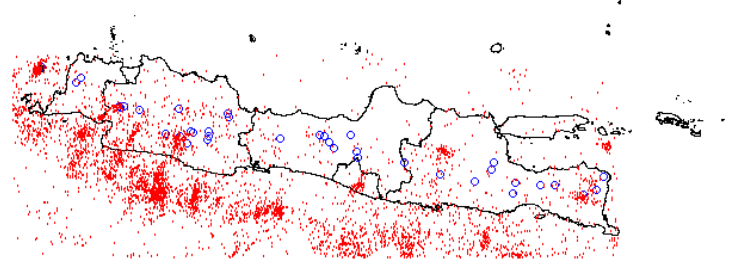

Gambar 3.2. Jarak Gunung Berapi dengan Kejadian Gempabumi di Pulau Jawa

Berdasarkan Gambar 3.2, secara visual terlihat bahwa lokasi gunung berapi membentang di bagian daratan Pulau Jawa sedangkan kejadian gempabumi yang terjadi di Pulau Jawa didominasi berada di bagian selatan Pulau Jawa dan terjadi di laut bagian selatan Pulau Jawa. Letak gunung berapi tersebar dari bagian barat hingga timur Pulau Jawa dengan persebaran yang hampir merata. Hal ini juga berlaku pada kejadian gempabumi yang terjadi hampir menyebar di seluruh bagian selatan Pulau Jawa.

\section{Langkah Analisis Visualisasi Jarak Subduksi dengan \\ Kejadian Gempabumi di Pulau Jawa}

Berikut merupakan hasil visualisasi lokasi subduksi dengan kejadian gempabumi di Pulau Jawa.

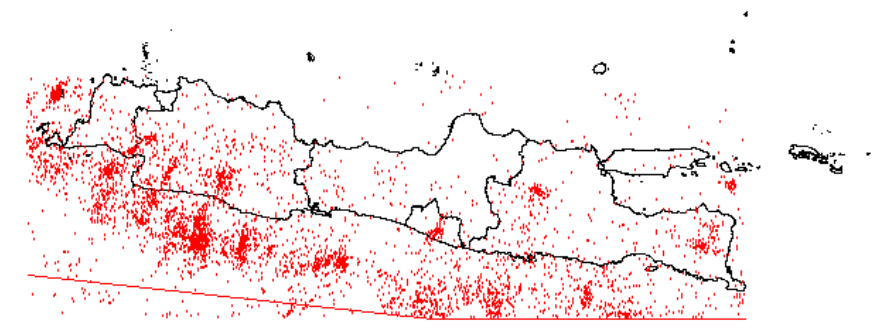

Gambar 3.3. Jarak Subduksi dengan Kejadian Gempabumi di Pulau Jawa

Garis merah memanjang yang terletak di bagian selatan Pulau Jawa merupakan zona subduksi. Zona subduksi adalah zona yang menunjam masuk ke bawah lempeng benua sebagai batas pertemuan antar lempeng samudera . Pada Gambar 3.3 dapat diketahui bahwa secara visual kejadian gempabumi di Pulau Jawa mengikuti zona subduksi yang 
melewati Pulau Jawa. Pada sisi bagan timur Pulau Jawa gempabumi yang terjadi berdekatan dengan zona subduksi.

\section{Uji Stasioneritas}

Berkut ini merupakan pengujian stasioneritas data spasial yang digunakan untuk mengetahui data yang digunakan dibangkitkan dari proses stasioner atau tidak.

Tabel 3.1 Hasil Pengujian Data Spasial

\begin{tabular}{cclc}
\hline $\boldsymbol{X}^{\mathbf{2}}$ & P-Value & Hipotesis & Keputusan \\
\hline 7004 & 0,0000 & $\mathrm{H}_{0}:$ SPP & Tolak $\mathrm{H}_{0}$ \\
& dibangkitkan dari & \\
& proses yang & \\
& stasioner & \\
& $\mathrm{H}_{1}:$ SPP & \\
& dibangkitkan dari & \\
& proses yang tidak & \\
& stasioner & \\
\hline
\end{tabular}

Tabel 3.1 menunjukkan hasil pengujian dari data spasial yang digunakan dalam penelitian ini dengan menggunakan Uji Chi-Square. Taraf signifikansi yang digunakan dalam pengujian ini sebesar $\alpha=0,05$ dan didapatkan hasil P-Value sebesar 0,000 . Sehingga nilai $P$-Value yang didapatkan lebih kecil dari taraf signifikansi, maka keputusan yang diambil adalah menolak $\mathrm{H}_{0}$. Kesimpulan yang didapatkan adalah data SPP yang digunakan dibangkitkan dari proses yang tidak stasioner.

\section{E. Ripley K-Function}

Sebaran data dapat diketahui dengan menggunakan $K$ Function Plot seperti di bawah.

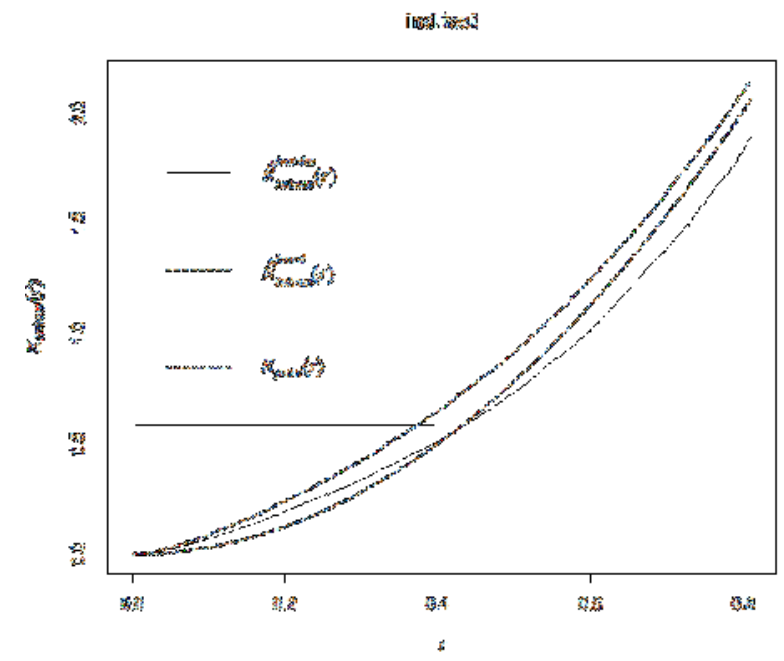

Gambar 3.4 K-Function Plot untuk mendeteksi sebaran data

Gambar 3.4 menunjukkan bahwa dari pengujian secara visual yang dilakukan dengan menggunakan K-Function plot sebaran data yang digunakan dalam penelitian ini cenderung membentuk kelompok-kelompok atau mengklaster. Hal ini ditunjukkan dengan garis $\mathrm{K}$-Funtion dengan edge correction untuk data yang tidak masuk ke dalam kelompok pengamatan berada di atas garis K-Function untuk poisson.

\section{F. Estimasi Parameter}

Estimasi parameter pada penelitian ini dilakukan menggunakan metode second order composite likelihood. Dari estimasi yang telah dilakukan, diperoleh hasil yang dapat dilihat pada Tabel 3.2 berikut.

Tabel 3.2 Estimasi Parameter

\begin{tabular}{ccrc}
\hline Parameter & Koefisien & Exp(Koef) & $P$-value \\
\hline $\boldsymbol{\beta}_{\mathbf{0}}$ & -2.7716693 & 0.062558 & $2.65 \mathrm{E}-19$ \\
$\boldsymbol{\beta}_{\mathbf{1}}$ & -0.0077566 & 0.992273 & $5.07 \mathrm{E}-11$ \\
$\boldsymbol{\beta}_{\mathbf{2}}$ & -0.0068625 & 0.993161 & 0.000162 \\
\hline
\end{tabular}

Tabel 3.2 menunjukkan bahwa jarak antara gunung dan subduksi secara statistik, signifikan berpengaruh signifikan terhadap jumlah gempa yang terjadi di sekitar wilayah tersebut. Dari hasil estimasi yang telah dilakukan, diperoleh model sebagai berikut.

$$
\begin{gathered}
\hat{\rho}(u)=\hat{\alpha} \hat{\gamma} \times \exp \left[-2.7716693-0.0077566 Z_{1}(u)\right. \\
\left.-0.0068625 Z_{2}(u)\right]
\end{gathered}
$$

Dari model diatas diperoleh informasi bahwa, jika :

1. Jarak suatu lokasi dengan gunung berapi dan zona subduksi 0 , maka peluang terjadi gempa dilokasi tersebut sebesar 0.0623

2. Jarak suatu lokasi ke gunung berapi tetap, tetapi jarak lokasi tersebut ke zona subduksi bertambah satu satuan, maka peluang terjadi gempa di lokasi tersebut lebih kecil 0.992 kali.

3. Jarak suatu lokasi ke zona subduksi tetap, tetapi jarak lokasi tersebut ke gunung berapi bertambah satu satuan, maka peluang terjadi gempa di lokasi tersebut lebih kecil 0.993 kali.

G. Hasil Prediksi

Dari model yang sudah didapatkan, diperoleh hasil prediksi gempabumi di pulau jawa sebanyak 4514 dimana hasil prediksi tersebut sudah sesuai dengan jumlah gempa yang ada di pulau jawa. Gambar 3. 5 berikut merupakan visualisasi dari lokasi gempa hasil prediksi.

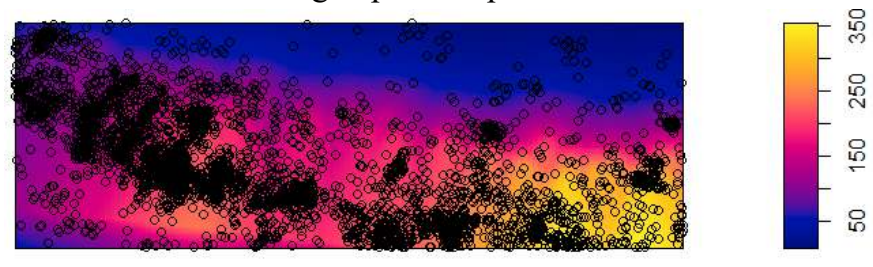

Gambar 3.5 Prediksi Lokasi Gempabumi

Dari hasil prediksi pada Gambar 3.5, diketahui bahwa wilayah pulau Jawa Timur diprediksi sering terjadi gempabumi. Hal tersebut didukung dengan fakta hasil penelitian dari para ahli geologi ITS yang dikutip dari kompas.com bahwa terdapat dua sumber gempa di Jawa Timur yaitu adanya tumbukan lempeng di selatan Jawa Timur 
dan sesar aktif Jawa. Kedua sumber gempa tersebut mengancam sebagian besar wilayah di Jawa Timur dan menimbulkan potensi Tsunami terutama di wilayah yang dilalui pantai Selatan. Sesar aktif di Jawa Timur melewati Banyuwangi, Pasuruan, Probolinggo, Pasuruan, Surabaya, Waru, Caruban, Sidoarjo, Mojokerto, Jombang, dan Nganjuk. Hal inilah yang menyebabkan sebagian besar hasil prediksi gempabumi berada di Jawa Timur.

\section{KESIMPULAN DAN SARAN}

\section{A. Kesimpulan}

Berdasarkan analisis yang telah dilakukan maka dapat diambil kesimpulan diantaranya sebagai berikut.

1. Gempabumi di Pulau Jawa pada tahun 2009 sampai 2018 menyebar di seluruh bagian Pulau Jawa. Jumlah gempabumi sebanyak 4514 gempabumi dan paling banyak terjadi di bagian barat Pulau Jawa. Persebaran gunung berapi dan gempabumi merata di Pulau Jawa. Zona subduksi pada Pulau Jawa terletak membentang dari timur hingga barat Pulau Jawa.

2. Hasil prediksi gempabumi di pulau jawa sebanyak 4514 dimana hasil prediksi tersebut sudah sesuai dengan jumlah gempa yang ada di pulau jawa. Sebagian besar hasil prediksi menunjukkan gempa terjadi di Jawa Timur karena Jawa Timur merupakan pertemuan dua lempeng dan sesar Jawa.

B. Saran

Saran yang dapat diberikan untuk pemetaan hasil prediksi gempa bumi di Pulau Jawa dalah menambah kovariat pada penelitian, seperti menambah kovariat Sesar. Karena dengan melakuka hal itu, pemetaan hasil prediksi gempa bumi di Pulau Jawa lebih akurat.

\section{DAFTAR PUSTAKA}

[1] L. A. Nugraha, Supardi dan A. Supriyadi, "Evaluasi Kekuatan dan Detailing Tulangan Kolom Beton Bertulang Sesuai SNI 2847:2013 dan SNI 1726:2012 (Studi Kasus : Hotel 10 Lantai di Semarang)," e-Jurnal Matriks Teknik Sipil, vol. Vol. II, No. 12, pp. 887-894, 2017.

[2] J. Nugraha, G. Pasau, B. Sunardi dan S. Widiyantoro, "Analisis Hazard Gempa dan Isoseismal untuk Wilayah Jawa-Bali-NTB", Jurnal Meteorologi dan Geofisika, vol. Vol. 15, no. No. 1, pp. 111, 2014.

[3] BMKG. Gempabumi Edisi Populer. Gempabumi Edisi Populer, 26, 2012

[4] A. Baddeley, Spatial Point Processes and their Applications. Australia: School of Mathematics \& Statistics, University of Western Australia, 2006.

[5] A. Choiruddin, J.F. Coeurjolly, and F. Letué, Convex and nonconvex regularization methods for spatial point processes intensity estimation. Electronic Journal of Statistics, Vol. 12 No. 1, pp. 1210-1255, 2018. 